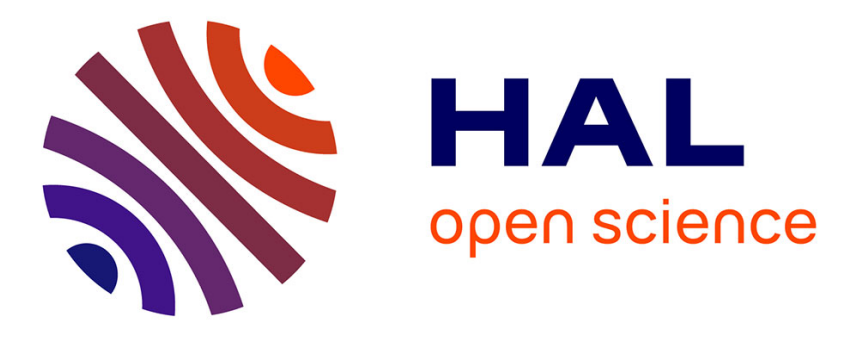

\title{
Reciprocal interactions between plants and fluorescent pseudomonads in relation with iron in the rhizosphere
}

Laure Avoscan, Gérard Vansuyt, Jeannine Lherminier, Christine Arnould, Geneviève Conejero, Eric Bernaud, Philippe P. Lemanceau

\section{- To cite this version:}

Laure Avoscan, Gérard Vansuyt, Jeannine Lherminier, Christine Arnould, Geneviève Conejero, et al. Reciprocal interactions between plants and fluorescent pseudomonads in relation with iron in the rhizosphere. 5. Journées Scientifiques et Techniques du Réseau des Microscopistes INRA, Nov 2014, Dijon, France, 12-14 novembre 2014, France. 2014. hal-01837545

\section{HAL Id: hal-01837545 https://hal.science/hal-01837545}

Submitted on 3 Jun 2020

HAL is a multi-disciplinary open access archive for the deposit and dissemination of scientific research documents, whether they are published or not. The documents may come from teaching and research institutions in France or abroad, or from public or private research centers.
L'archive ouverte pluridisciplinaire HAL, est destinée au dépôt et à la diffusion de documents scientifiques de niveau recherche, publiés ou non, émanant des établissements d'enseignement et de recherche français ou étrangers, des laboratoires publics ou privés. 


\section{Reciprocal interactions between plants and fluorescent pseudomonads in relation with iron in the rhizosphere}

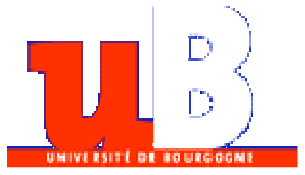

\section{Avoscan ${ }^{1}$, G. Vansuyt ${ }^{1}$, J. Lherminier², C. Arnould ${ }^{2}$, G. Conejero ${ }^{3}$, E. Bernaud ${ }^{1}$, and P. Lemanceau ${ }^{1}$}

1. UMR Microbiologie du Sol et de l'Environnement, INRA/Université de Bourgogne, CMSE, BP 86510, 21065 Dijon cedex, France

2. Centre de Microscopie, INRA/Université de Bourgogne, CMSE, BP 86510, 21065 Dijon cedex, France

3. Plate-forme d'Histocytologie et Imagerie Cellulaire Végétale, UMR Biochimie et Physiologie Moleculaire des Plantes INRA CNRS

UM2 SupAgro avenue Agropolis Cirad 34398 Montpellier Cedex 5

laure.avoscan@dijon.inra.fr

\section{INTRODUCTION}

Iron is an essential element for plants and microbes. Iron competition was demonstrated to be an important driver of the interactions between fluorescent pseudomonads and the rhizospheric microflora (Lemanceau et al., in press). To face this competition, plants and microorganisms have developed active strategies of iron uptake. In non graminaceous plants (strategy I), iron uptake relies on acidification and reduction of $\mathrm{Fe}$ (III) to $\mathrm{Fe}$ (II) which is incorporated into the roots by iron transporters (eg. IRT1). Active iron uptake by microorganisms relies on siderophores showing high affinity for iron.

We have previously shown that plants of Arabidopsis thaliana (strategy I) supplemented with Fe-pyoverdine had (i) a higher iron content than those supplemented with Fe-EDTA, (ii) iron incorporation from pyoverdine did not involve IRT1, and (iii) ${ }^{15} \mathrm{~N}$-labeled pyoverdine was incorporated in planta (Vansuyt et al., 2007). Taken together, these observations suggest that iron from Fe-pyoverdine was incorporated in planta not through the strategy I. In the present study, we explored possible mechanisms for incorporation of iron from pyoverdine at the cellular level.

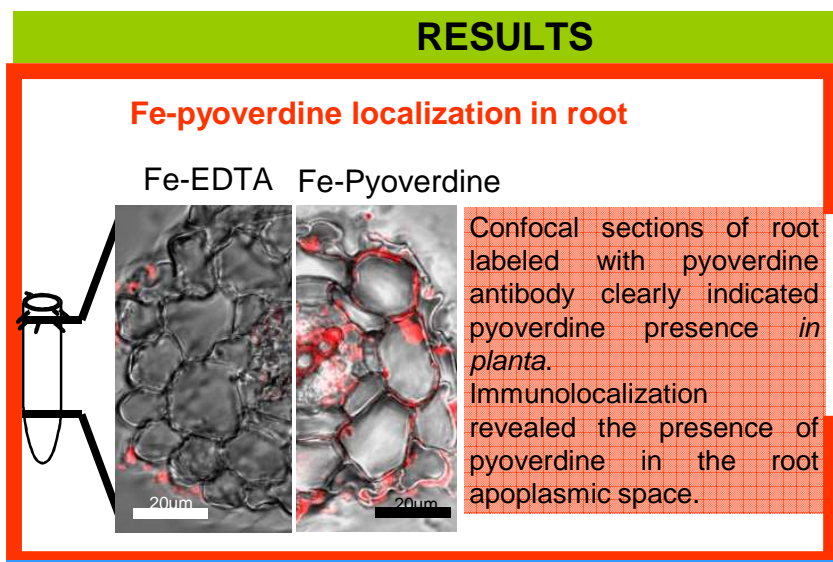

Incorporation of Fe-pyoverdine by endocytosis ?

Monitoring endocytosis by uptake of the endocytosis marker FM4-64 might indicate that incorporation of Fe-pyoverdine relies on endocytosis
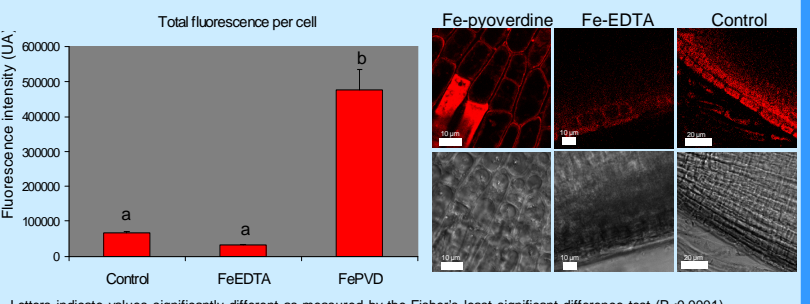

Letters indicate values significantly different as measured by the Fisher's least significant difference test $(P<0.0001)$

\section{CONCLUSION}

Observations and quantification with TEM showed a more abundant presence of vesicles in the root apoplasm of plants when cultured with Fe-pyoverdine than with Fe-EDTA. However pyoverdine immunogold labeling of root sections was not sensitive enough to allow the possible detection of pyoverdine in the vesicles. Altogether, these data confirm the acquisition of iron from Fe-pyoverdine by $A$. thaliana and suggest that iron incorporation from Fe-pyoverdine could be related to endocytosis. Further experimental proof is required to determine if the increase of vesicles in the presence of pyoverdine mediates that process.

References

Vansuyt G. et al., 2007. Iron acquisition from Fe-pyoverdine by Arabidopsis thaliana. Mol. Plant-Microbes Interact. 20:441-447.

Lemanceau P. et al., 2009. Iron dynamics in the rhizosphere as a case study for analysing interactions anceau P., et al. Role of Iron in Plant-Micr

\section{MATERIALS AND METHODS}

\section{In vitro culture of Arabidopsis plants}

Plants cultured for seven days without any iron supplementation and for seven more days after having been supplemented with Fe-pyoverdine or Fe-EDTA or not supplemented

Sampling of 14-day old roots for ultrastructural studies with transmission electron microscopy (TEM) and immunolocalization of pyoverdine in roots by confocal microscopy and TEM

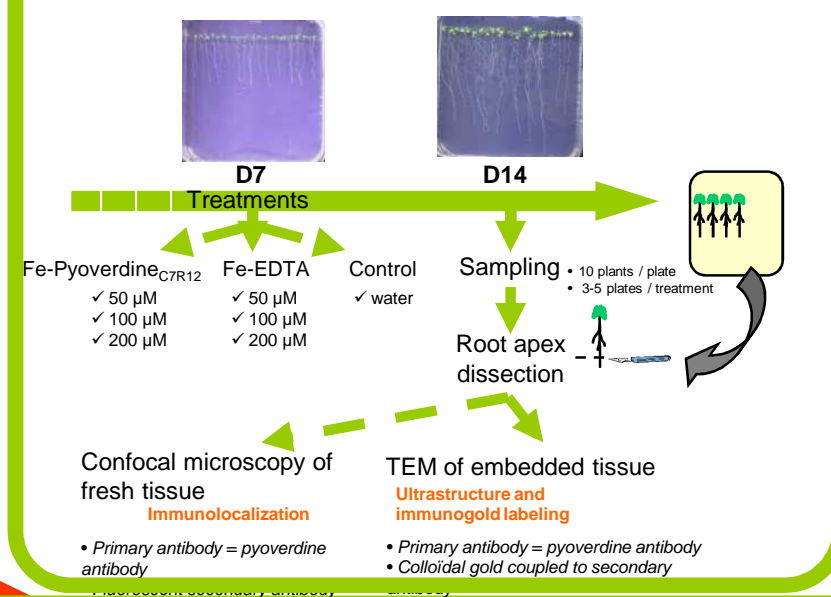

Ultrastructural analysis of root cells supplemented with Fepyoverdine, Fe-EDTA or not supplemented

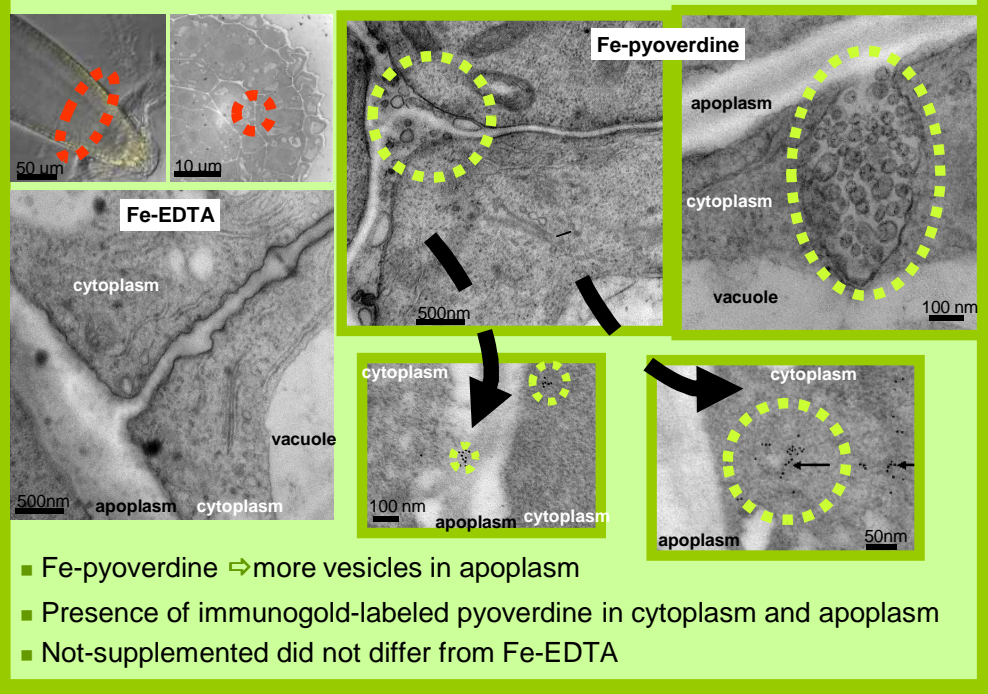

Quantification of apoplasmic vesicles in root cells
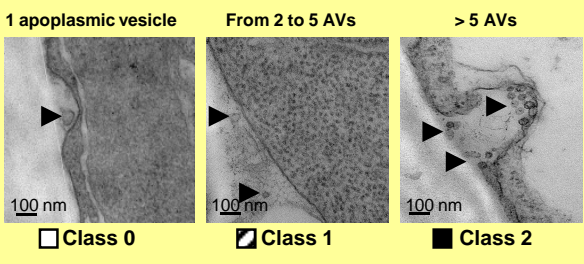

For each sectioned cell, apoplasmic vesicles (AVs) were classified into three classes and results are expressed in percentage of cells exhibiting 1 , $2-5$ and $>5$ AVs per cell
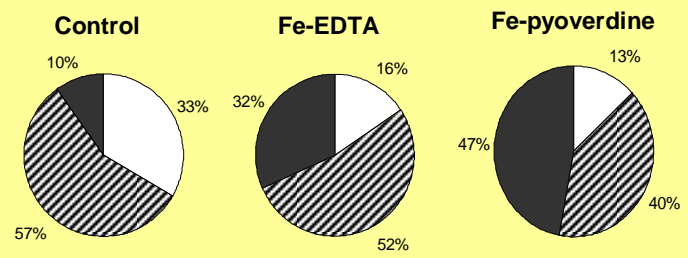